\title{
Economic Determinants of Divorce Among Dual-Earner Couples: Jews in Israel
}

\section{Les déterminants économiques du divorce parmi les couples à double revenu : le cas des juifs en Israël}

\section{Liat Raz-Yurovich}

Received: 20 May 2011/ Accepted: 13 February 2012

(C) Springer Science+Business Media B.V. 2012

\begin{abstract}
The second half of the twentieth century saw tremendous changes in the economics of the household, as women entered the labor force in growing numbers and the share of dual-earners couples increased. These changes challenge the available theories which explain divorce by economic factors, as they are mostly molded in the homemaker-breadwinner model. In this study, we investigate the validity of two main groups of theories: one which asserts that women's work has a destabilizing effect on marriage, and assumes asymmetry between the spouses; and another which states that women's employment has a stabilizing effect, and assumes that relations between spouses are symmetric. By employing a large-scale longitudinal register-based data for the Jewish population in Israel, we find asymmetry in the effect of the spouses' economic characteristics on marital instability, which suggest that theories that assert asymmetry and power relations between the spouses better explain transition to divorce among this group. In line with theories of income pooling, higher shared salaries are found to increase marital stability. Nonetheless, our results demonstrate that the basic assumption of symmetry between the spouses in these theories does not hold. Although employment stability for both spouses appears to reduce divorce risk, only the husband's salary is shown to negatively affect the odds of divorce and only the wife's working hours and sector of employment affect marriage instability. Moreover, couples in which the wife earns as much as or more than the husband are found to have the highest divorce risk.
\end{abstract}

Keywords Divorce - Dual-earner - Dual-career - Employment stability · Israeli families $\cdot$ Marital dissolution $\cdot$ Paid work $\cdot$ Register-data

\footnotetext{
L. Raz-Yurovich $(\bowtie)$

Laboratory of Economic and Social Demography, Max-Planck Institute for Demographic Research, Konrad-Zuse Strasse 1, 18057 Rostock, Germany

e-mail: raz@demogr.mpg.de
} 
Résumé Des changements considérables ont été observés dans la situation économique des ménages au cours de la seconde moitié du 20e siècle avec l'entrée croissante des femmes sur le marché du travail et l'augmentation de la proportion de couples bi-actifs. Ces changements interpellent les théories existantes qui mettent en avant les facteurs économiques pour expliquer le divorce, car elles s'inscrivent dans le modèle personne au foyer - soutien de famille. Dans cet article, nous examinons la validité des deux principaux groupes de théories : le premier qui affirme que le travail des femmes est un facteur de déstabilisation du mariage et suppose une asymétrie entre conjoints, le second qui postule que le travail des femmes est un facteur de stabilisation et se base sur l'hypothèse que les relations entre conjoints sont symétriques. A partir de données longitudinales de registres concernant une large partie de la population juive en Israël, une asymétrie dans l'effet des caractéristiques économiques des conjoints sur l'instabilité conjugale est observée, ce qui laisse supposer que les théories qui considèrent une asymétrie et des relations de pouvoir entre les conjoints expliquent mieux la survenue du divorce dans ce groupe. Conformément à la théorie de mise en commun des revenus, des salaires partagés plus élevés augmentent la stabilité maritale. Néanmoins, nos résultats montrent que l'hypothèse de base de symétrie entre les époux dans ces théories n'est pas vérifiée. Bien que la stabilité de l'emploi pour les deux conjoints semble diminuer le risque de divorce, seul le salaire du mari affecte négativement les chances de divorce et seul le nombre d'heures de travail de la femme et le secteur d'activité ont un impact sur l'instabilité maritale. En outre, les couples où le salaire de la femme est similaire ou supérieur à celui du mari ont le risque de divorce le plus élevé.

Mots-clés Divorce · Double revenu · Double carrière · Stabilité de l'emploi · Familles israéliennes · Dissolution du mariage · Travail rémunéré .

Données de registre

\section{Introduction}

In an era in which most families in the Western developed world are dual-earner (Blossfeld and Drobnic 2001; Stier 2010; Waite and Nielsen 2001) and the relative shares of economic contributions by men and women to the household income are changing; and in light of the changing foundations of family formation, from household production to household consumption (Cherlin 2000; Stevenson and Wolfers 2007); it is essential to test whether the available theoretical perspectives on marriage dissolution are still relevant in an examination of modern family forms. The current study maps the main theories that explain differences in divorce rates by economic variables, and uses a unique set of register-based data for Jewish dualearner couples in Israel from the late 1990s to clarify the theoretical typology which these perspectives suggest. This paper is an addition to the relatively small number of existing studies on the economic determinants of divorce that have also used register-based data from different countries [for example, Jalovaara $(2001,2003)$ 
from Finland; Hansen (2005) and Lyngstad (2011) from Norway; Kalmijn et al. (2007) from the Netherlands; and Henz and Jonsson (2003) and Dribe and Stanfors (2010) from Sweden]. As our dataset links between population registry data and census data, it yields a longitudinal design and a large sample size, both of which are a prerequisite for any meaningful study on antecedents of divorce. The Jewish population in Israel was chosen because the institutions of marriage and divorce are still relevant for processes of union creation and dissolution among this population (Raz-Yurovich 2010). Moreover, dual-earner families are the most common type of family in this group, and constitute over $60 \%$ of all families in the study period (Stier 2010).

Dual-earner couples are not a homogeneous group, and different types of dualearner couples might have different levels of divorce risk. Although Nock (2001) has argued that the marriages of equally dependent spouses (in which each partner generates between 40 and $59 \%$ of the family earnings) are becoming increasingly common, Moen and Sweet (2003) have shown that there are variations among dualearner couples in the allocation of the labor market investments of each of the spouses, and also in their quality-of-life levels (i.e., level of satisfaction with the relationship, level of vitality, availability of free-time, etc.). Moreover, Stier and Lewin-Epstein (2000) have found that the part-time or full-time employment of the wife affects various aspects of household arrangements and the degree of gender equality in the household. Lundberg and Pollak (1996) further suggest that households with different ratios of wife's earnings might face different prices and may have different preferences.

Most of the economic and sociological theories that seek to explain the relationship between economic activity and marriage dissolution focus mainly on the effect of women's economic activity on divorce. Some of them suggest that wives' economic activity has a destabilizing effect on marriage (Becker 1991; Brines 1994; Lundberg and Pollak 1996; Manser and Brown 1980; Nock 1995, 2001; Parsons 1940), while other theoretical perspectives assert that it has a stabilizing effect (Cherlin 2000; Moffitt 2000; Oppenheimer 1977; Rogers 2004). Each of these groups of theories is based on different underlying assumptions regarding the existence of asymmetry or symmetry between the spouses.

Most of these theories focus mainly on wages as the operationalization for economic activity, and fail to consider other economic or employment characteristics which might affect both the salary and the divorce risk of the couples. In this study, we employ data for first marriages among the Jewish population in Israel that were intact at the 1995 census, and for divorces between 1995 and 1998, to analyse how a wide range of economic and employment characteristics of dual-earner couples affect their propensity to divorce.

The crude divorce rate among Jews in Israel in 2009 was 1.9 per 1,000 population (Israel Central Bureau of Statistics 2011), in comparison to 3.4 in the US (US Department of Health and Human Services 2010). In 1998, at the end of our study period, crude divorce rates of Israeli Jews were 1.8. By comparison, the corresponding rates in 1998 were 2.7 in the UK and in Finland, 2.6 in Belgium, 2.5 in Denmark and Switzerland and 2.3 in Germany; only a few countries had lower rates, such as Iceland (1.8), Poland (1.2), Spain (0.9), Italy (0.6), and Ireland 
(0.4) (European Commission 2010). Despite its relatively low divorce rates, the Jewish population in Israel has recently experienced an increase in divorce and the cumulative divorce probabilities have increased from $4.8 \%$ after 5 years of marriage for couples married in 1968-1971, to about $9.3 \%$ for couples married in the mid-1990s (ICBS 2009). These relatively low divorce rates can be attributed to its traditional characteristics, and not to the existence of substitutes to marriage or to divorce. According to the Israel Central Bureau of Statistics (ICBS 1998, 2011) only $3 \%$ of the Jewish men and $4 \%$ of the Jewish women never married by ages 40-44, in 1995 . In $2009,12 \%$ of the men and $15 \%$ of the women never married by these ages. These statistics demonstrate that marriages are almost universal in Israel, especially during the study period. Moreover, according to the ICBS (2010a), only in $3 \%$ of the cohabiting unions in 2008 at least one of the spouses was still "married" or "separated", rather than divorced (31\%), widowed $(6 \%)$, or single $(60 \%)$. As the majority $(58 \%)$ of Jewish people aged 20 and above define themselves as either traditional or religious (ICBS 2010b), living with a new spouse without divorcing may be regarded as unacceptable. Moreover, if the separated woman will have children from another man, these children will be considered bustards under the Jewish law. Therefore, this law provides incentives for formal divorce among women in fertility ages.

Compared to other Western developed countries, Israel is also characterized by relatively high fertility rates (TFR of Israeli women was 2.97 in 2010 and 2.62 during the 1990s) (ICBS 2011). Even among secular Jews fertility levels are higher in comparison to the US and all European countries (Okun 2012). Moreover, the Jewish population is characterized by relatively high labor force participation rates (LFPR) among women in general and mothers in particular, and a high percentage of women who are in full-time employment (Mandel and Semyonov 2006). Mandel and Semyonov (2006) demonstrated that out of 22 developed countries in the late 1990s, only 10 countries had higher LFPR among women than Israel (where $65 \%$ of all women aged 25-60 were in the labor force), and only eight countries had higher LFPR among mothers of preschool children than Israel (where about $55 \%$ of all mothers of preschool children were in the labor force). Moreover, Mandel and Semyonov demonstrated that only six out of 19 countries have higher percentages of women who work full-time than Israel (where about half of all employed women aged 25-60 worked in full time jobs). ${ }^{1}$ However, family life and motherhood are strongly emphasized in Israeli culture (Toren 2003), and Israeli women are expected to take on the main responsibilities for the household chores and for raising the children, regardless of their labor market activity (Glickman et al. 2003; Izraeli 1997). Nonetheless, our own calculations using the ISSP 2002 database (ISSP 2002) show that, although the average Israeli Jewish woman is responsible for $63 \%$ of the total time invested in household labor by both spouses, only seven Western developed countries out of the 26 countries that are included in this database have a more egalitarian division than Israel. These unique characteristics of Jewish Israeli

\footnotetext{
1 It is important to note that Mandel's and Semyonov's data on Israel included not only Jewish women, but also significant populations of non-Jewish (primarily Arab population) women whose labor force participation rates are much lower. Hence we would expect higher rates for Israel if we were to look only at Jewish women.
} 
society might affect the work-family conflict experienced by both the husband and the wife in a dual-earner partnership, and may in turn affect the quality of their work lives, their family lives, and their life satisfaction in general (Higgins and Duxbury 1992; Higgins et al. 1992). Thus, the threshold for divorce among Israeli dual-earner couples may differ from that of dual-earner couples in other Western developed countries.

By analyzing the economic determinants of divorce among Jewish dual-earner couples in Israel, this study will investigate the validity of two main groups of theories which explain divorce by economic factors. One group of theories asserts that women's work has a destabilizing effect on marriage and assumes asymmetry between the spouses; and the other asserts that women's employment has a stabilizing effect, and assumes that relations between spouses are symmetric.

\section{Theoretical Background}

Most of the theories on the relationship between economic activity and the transition to divorce concentrate on the role of the wife's, rather than the husband's, employment in promoting marital instability. While some theories suggest a destabilizing effect of women's economic activity on marriage, others suggest a stabilizing effect. Each of these theoretical perspectives is closely related to a different measurement of salary and offers different mechanisms through which economic activity affect marital stability. These theories are not monolithic, and should be regarded as individual mechanisms which might operate concomitantly.

\subsection{Women's Economic Activity as a Destabilizing Factor for Marriage}

The most widespread theoretical perspectives on the destabilizing effect of wives' labor market activity are based on Becker's (1991) and the New Home Economists' (Becker et al. 1977) claim that the gain from marriage is highest for both spouses when specialization and pronounced differentiation in gender roles exist within the household. In the context of dual-earner families, Becker's basic assumption of full specialization has to be relaxed to allow for the fact that that the wives in these families make some contribution to the household income. Nonetheless, partial traditional specialization might exist if women are only secondary breadwinners. Becker's assertion that "the gain from marriage is reduced, and hence the attractiveness of divorce is raised, by higher earning and labor force participation of married women" (1991, p. 55) has been summarized by the various studies that have investigated this claim as the role specialization hypothesis (Schoen et al. 2002), the wife's independence hypothesis (Ono 1998; Rogers 2004), the specialization and trading hypothesis (Oppenheimer 1997; Schoen et al. 2002), the interdependence hypothesis (Schoen et al. 2002), the "price" effect (Moffitt 2000), or the division of labor hypothesis (Poortman and Kalmijn 2002). All of these hypotheses suggest that, when wives have higher earnings, the propensity of both spouses to divorce increases because the interdependence between them no longer exists-i.e., the wife is no longer dependent on her husband's income and is 
free to leave the marriage because she can support herself-and the husband does not receive the level of household services he would expect under the assumption of full specialization. Because the basic assumption of Becker's theory is that the husband specializes in the labor market and is the household's main breadwinner, the theory predicts that higher earnings for men would enhance marriage stability.

Becker's economic model assumes that having a higher household income will increase marital stability. However, it also assumes that there is only one contributor to the family's income, and that this contributor (the husband) is an altruist who makes decisions so that the (single) utility function of the household will be maximized. In their bargaining model, Manser and Brown (1980) and Lundberg and Pollak (1996) criticize Becker's model, and contend that it attributes power in decision making only to the husband. The bargaining model assumes that each of the spouses has a different utility function, and that the spouses try to reach an agreement while maximizing their individual utility functions. If they fail to reach an agreement, divorce might occur. This model assumes that there are power struggles between the spouses, and that control over resources increases each partner's bargaining power. Thus, what matters is not only the total household income or the resources controlled by each of the spouses, but also the fraction of resources controlled by the wife (Pollak 1994). According to this view, the woman's economic independence increases her bargaining power within the household regarding, for example, a more favorable division of household labor. In this dynamic, the risk that the woman will initiate divorce might depend on the level of the husband's participation in domestic chores or his investment in labor market activities (Cooke 2006; De Graaf and Kalmijn 2006).

Another theoretical perspective on the destabilizing effect of wives' employment is Parsons' status competition theory (Parsons 1940). This theory asserts that, when both spouses are career-oriented, intra-familial stress may occur due to status competition between the spouses, and this might lead to divorce. While Parsons does not argue that women should avoid working, he does appear to suggest that a woman's employment status or salary should not exceed or compete with her husband's status or earnings. According to Oppenheimer (1977), the gender asymmetry which characterizes Parsons' theory stems from his assertion that there is a long-standing norm in society that the husband should be the main provider and status determiner in the family. Therefore, according to this theory, couples in which the wife has a higher career status than her husband (in terms of educational level, employment category, salary, etc.) would be more prone to divorce. As in Becker's theory, the husband's economic standing is supposed to have a stabilizing effect on marriage due to his role as the main breadwinner. A similar perspective can be found in the feminist theories of doing gender (West and Zimmerman 1987) or gender display (Brines 1994; Goffman 2007). According to these theories, when traditional perceptions of gender roles exist in a society, a wife who earns more than her husband is not fulfilling her socially accepted gender role, and is therefore more prone to divorce (Blossfeld and Müller 2002).

Yet another perspective regarding the positive effect of women's economic activity on divorce can be found in Nock's (1995, 2001) equal dependency hypothesis. According to this hypothesis, equally dependent spouses, in which each 
of the partners generates 40 to $59 \%$ of the family earnings, will have the highest probability of divorce, because the women in these couples have the lowest degree of commitment to marriage. In addition, according to Rogers (2004), the equal dependency hypothesis suggests that both spouses can initiate divorce, because their financial obligations to each other are weakest when their economic contributions are similar. Nonetheless, according to the role collaboration hypothesis (Rogers 2004), the equal dependency of the spouses will make marriage more stable because there is more equality between the partners; this might, however, be dependent on the gender expectations of the spouses and on perceptions of equality in marital relationships.

To sum, the theories that were described above suggest different mechanisms, which might act simultaneously, through which women's economic activity might positively affect divorce. Among these mechanisms are the breakdown of marital specialization, the increased independence of women and the competition that women's economic activity evokes between the spouses.

\subsection{Women's Economic Activity as a Stabilizing Factor in Marriage}

Most of the theories regarding the stabilizing effect of women's economic activity on marriage arose from criticism of the role specialization hypothesis of Becker (1991). According to Cherlin (2000) and Stevenson and Wolfers (2007), the specialization model is no longer relevant in the twenty-first century because the basis of intimate relationships changed during the second half of the twentieth century, from specialization and household production to income pooling and household consumption. In line with this criticism, the income effect (Greenstein 1990; Moffitt 2000) or economic partnership (Rogers 2004) perspectives assert that having a higher shared income will allow the spouses to maintain higher standards of living, and also to support one another in times of hardship (e.g., illness, unemployment, educational enrollment, etc.). Moreover, the shared marital assets of the spouses will increase the barriers to divorce, because these would be reduced if divorce were to occur. Therefore, according to these theories, having a shared income to which both spouses contribute will have a stabilizing effect on marriage.

The status maintenance and status enhancement theory of Oppenheimer (1977) asserts that a woman's employment might help in enhancing her family's position in the social stratification system. According to this theory, both family members and people outside the family evaluate the social standing of the family based on both the husband's and the wife's employment. Therefore, if the wife earns much less than her husband, this would necessarily reduce the social standing of the family. Thus, in contrast to the status competition theory, this theory argues that a woman's high economic status enhances rather than destabilizes her marriage.

Unlike Becker's model, these theories assume that both spouses contribute to the family income, and that greater earnings stabilize marriages irrespective of which spouse earned them. Thus, these theories do not take into account possible power struggles between the spouses. Instead, they assume that there is symmetry between the partners. These theories further suggests that the underline mechanisms that explain the negative effect of women's economic activity on divorce is that 
women's earned income is, in some cases, a necessity to the household income and also operates as one of the status symbols of the household.

\subsection{Derived Hypotheses on the Effect of Salary Measures on Divorce}

\subsubsection{The Sum of Spouses' Earnings}

Because Becker's theory predicts a negative effect of the husband's earnings, but a positive effect of the wife's earnings on divorce; we are not able to predict the direction or the strength of the effect of the total familial earnings among dualearner couples when this theory is applied. These two effects might offset one another, such that, depending on the strength and the direction of the effects of the spouses' salaries, the effect of the sum of earnings can be positive, negative, or equal to zero. The theories which predict a stabilizing effect of the wife's earnings on marriage assume that the total earnings of the spouses will have a negative effect on divorce.

\subsubsection{The Absolute Salary of Each of the Spouses}

It is derived from the two groups of theories that the husband's earnings will have negative effect on divorce. As for the wife's salary, Becker's theory is the only one among the first group of theories that directly refers to the effect of the wife's absolute earnings, and suggests a destabilizing effect on marriage for it. According to the second group of theories, which predicts a stabilizing effect of the wife's earnings on marriage, there is full symmetry between the spouses, so that the absolute earnings of each of the spouses are expected to have a negative effect on divorce.

\subsubsection{The Share of Earnings Contributed by the Wife}

Most of the theories which assert that women's economic activity has a destabilizing effect on marriage base their arguments on comparisons of the share of household income contributed by the wife and by the husband (e.g., the bargaining model, the status competition theory, the gender display theory, and the equal dependency hypothesis). These theories imply that, starting at a certain threshold value (e.g., $40 \%$ in the equal dependency hypothesis and $50 \%$ in the status competition hypothesis), when a higher share of the household earnings comes from the wife's earnings, the divorce risk increases. The theories predicting that a wife's earnings will have a stabilizing effect on marriage generally assume that the relative earnings of the spouses do not affect divorce risks, because what matters is the economic standing of the family, regardless of which spouse contributes more to the family's earnings.

Apart from the salary, other economic characteristics-such as education, the number of hours invested in the labor force, employment stability, sector of employment, and occupational type-might affect both marital stability and the salary of the spouses (Jalovaara 2001; Poortman and Kalmijn 2002). Becker et al. 
(1977) suggest, for example, that unforeseen events, such as unemployment of the husband, change the utility function of marriage and might increase the risk of divorce. Moreover, as according to this model the spouses are expected to specialize in different tasks, women's working hours are expected to have a positive effect on divorce. Moreover, Nock (2001) has found that the effect of being equally dependent spouses (i.e., the effect of relative earnings), becomes insignificant after the number of hours invested in the labor force is controlled for. Previous studies have also found that the intensity of the wife's work has a positive effect on divorce (Poortman and Kalmijn 2002; Spitze and South 1985). Nonetheless, when these studies analyzed the effect of working hours only among working women, Poortman and Kalmijn (2002) reported that the effect remained positive, while Spitze and South (1985) showed that the positive effect disappeared. Previous studies found that employment stability affects not only marriage formation (Kalmijn 2011; RazYurovich 2010) but also to marriage dissolution. Jensen and Smith (1990) found that only unemployment of the husband affects marriage dissolution, but most updated previous studies have found that the unemployment of either spouse can increase divorce risks (Charles and Stephens 2004; Hansen 2005; Jalovaara 2001; Nilsson 2008).

According to previous studies (e.g., Castles 2003; Okun et al. 2007), public sector employment provides conditions that are conducive to the combining of paid work and family life for women. Due to the family-friendly working conditions in the public sector relative to the private sector, it may be expected that public sector employment will reduce the risk of divorce among dual-earner couples.

Education is a very important confounder, as it affects both marital stability and earnings. According to Becker et al. (1977), there is no clear theoretical prediction about the net effect of schooling level on the gain from marriage. On the one hand, marriages between highly educated individuals have higher gains, because the spouses have higher levels of market and non-market skills. On the other hand, such marriages might have lower gains, because they involve less specialization between the spouses, as highly educated women participate more in the labor force. It is derived from this assertion that controlling for economic characteristics, the educational gradient of divorce should be negative. As is discussed in Matysiak et al. (2011), highly educated women might have lower divorce risks because they have better social, communication and cognitive skills; and they also experience less marital strain, as they enjoy higher standards of living. For a more thorough discussion on the educational gradient of divorce, see Härkönen and Dronkers (2006) and Matysiak et al. (2011).

\section{Data and Sample}

This research is based on a longitudinal database, created by Statistics Israel, which links a $20 \%$ sample of the Israeli 1995 census, annual register data from the National Insurance Institute of Israel (NIII) for the years 1983-1995, and the registration of divorces from the ministry of religious services and from the formal population registry of Israel for the years 1985-2007. Because our unit of analysis is 
the couple rather than the individual, and since we can only identify couples using census data, our analytic sample includes only couples who were still together at the time of the census (November 1995). ${ }^{2}$ Among these couples, we selected only those who married in Israel, for the first time (first marriage for both spouses), in the years 1990-1995, up to age 45. We used the registrations of divorce to analyze the transition to first divorce within three years; i.e., between November 1995 and December 1998. The census data provide information on marital status in 1995, and the exact year of the first and last marriages. In addition, the data contain information on the current (highest) educational levels and certificates (as of November 1995), and a list of variables which describe the employment characteristics of the respondent in 1995. The registered data from the NIII contain high quality data on annual salary and months of employment. Salary measures, which are based on register data, are much more reliable than salary measures which are based on the self-reports of respondents, especially if these are based on retrospective life histories. The information from the NIII is based on Israel's tax authority reports on salaried employees. Thus, salary and employment data from the NIII for a particular year or month are not available for people who were not salaried employees or did not participate in the civilian labor force during this time. This means that, for couples in which one of the spouses does not have reports on salary for the whole marriage duration, we cannot know whether this spouse was unemployed, self-employed, or serving in the army. Therefore, our analysis is restricted to couples in which both spouses worked as salaried employees for at least $20 \%$ of the marriage duration, but we cannot identify single-earner couples in which one spouse was not working at all as a salaried employee. Although the NIII's data are longitudinal, we cannot conduct a longitudinal analysis. We can, however, use this data to average the spouses' economic characteristics over the duration of the marriage (i.e., since the time of marriage and until 1995). This computation is less sensitive to year-to-year fluctuations in salary, and is therefore a better indicator than a measure that is based on one point in time. Moreover, averaging the couples' characteristics for the whole marriage duration gives a partial solution to the possibility of reverse causality, according to which individuals might increase economic activity prior to divorce in anticipation of the dissolution of the marriage. Overall, for $70 \%$ of the couples, we have full information on the salary for the whole marriage duration, and for the remaining $30 \%$, we average the salary based on salary reports for the available years. ${ }^{3}$ Therefore, our results can be generalized for salaried employees, who are the great majority of working men and women in Israel [in 1995, for example, $84 \%$ of Jewish employed men and $90 \%$ of Jewish employed women were salaried employees (ICBS 1996)]. Our sample might be

\footnotetext{
${ }^{2}$ Due to this, it is not possible to conduct a longitudinal analysis.

${ }^{3}$ It is important to note that the ability to identify only salaried employees is due to the source from which this data is derived and not due to data quality. The Tax Authorities registries were linked to the census data by the ICBS using full ID numbers, to assure accurate identification.
} 
subjected to a selection bias due to the exclusion of those couples in which at least one spouse was not working as a salaried employee over the whole marriage period. Moreover, another possible source of selection bias stems from the fact that the sample of people who formed marriages in 1990-1994 is a selected group, as the marriages of these people survived until 1995. In order to test the robustness of our results despite these shortcomings, we conducted two different tests. First, we ran the same models, by using salary and employment measures that are based only on the census data and not on the registries. In this way we could also include in the analysis unemployed individuals such as housewives; and also take into account earned income from self-employment. Nonetheless, the disadvantage of using the census data is that it refer only to one point in time (employment characteristics in September 1995), rather than to the whole marriage duration. Yet, this test demonstrated that the effect of the different economic characteristics on dualearners' marital stability is overall robust. Second, we compared the results received for the 1990-1994 marriage cohorts with those of the 1995 marriage cohort, and also compared the results received for each cohort separately. The results of these two tests also demonstrated that our results are overall robust.

Our analytic sample includes 13,041 married couples, 403 (3\%) of whom had divorced by the year 1998. This analysis does not refer to separation and does not include cohabitors, because we are not able to identify cohabitors in our database. Nonetheless, the inability to identify cohabitors is not so harmful as far as Israel is concerned, as in Israel it is mostly a precursor to-and not a substitute formarriage. This living arrangement is found mostly among a relatively small group of young, secular Jews (only $4 \%$ of all couples without children, and $2 \%$ of all couples with children, lived in cohabitation in 2008), and usually last for only a short period of time (Blush-Kleinman and Sherlin 1999; Fogel 2005; ICBS 2010a).

The sample is restricted to first marriages because it was found that remarriages are not as affected by economic dependence as first marriages (Heckert et al. 1998). In addition, as in previous studies, this study is not able to distinguish between the positive effect of the economic activity of women on divorce that is due to growing economic independence of the wife, and the positive effect that is due to the increase in economic activity in anticipation of divorce. However, as was mentioned above, because this study does not merely look at levels of economic activity immediately before divorce, but instead summarizes economic activity over a period of about five years prior to divorce, this problem of causality is reduced.

Logistic regression is used to estimate the transition to the first divorce within 3 years.

\section{Variables}

The dependent variable is the log-odds of a first divorce in the years 1995-1998; i.e., the $\log$ odds of divorce between November 1995 and December 1998. It is coded one if the first divorce occurred in those years, and zero otherwise. 


\subsection{Salary and Employment Measurements}

\subsubsection{The Log of the Average Monthly Salary}

The logs of the wife's and husband's average monthly salaries are computed separately by taking the log of the sum of the employed annual real salary of each over the course of the marriage (until the year 1995), divided by the number of months in which they were working as salaried employees over the course of the marriage. This computation is less sensitive to erratic year-to-year fluctuations in months employed due to, for example, unemployment, temporary illness, student status, etc. The annual real salary (in 1,000 Israeli shekels) is computed from nominal salaries with the consumer price index of the year 2006.

\subsubsection{Log of Total Household Salary}

The log of the sum of the average monthly salary of the spouses over the course of marriage.

\subsubsection{Share of the Wife's Salary}

This measure of relative earnings is constructed by computing the ratio between the wife's average monthly salary and the sum of the spouses' average monthly salaries over the course of marriage. Four dummy variables describe this ratio: the wife's share is less than $25 \%$, the wife's share is $25-50 \%$, the wife's share is $50-75 \%$ (the reference category), and the wife's share is $75-100 \%$.

\subsubsection{Number of Work Hours per Week}

Information regarding the number of hours each of the spouses invested in the labor market is available only from the census; therefore, this continuous variable describes the spouses' investment only in the year 1995.

\subsubsection{Public Versus Private Sector}

Information regarding the sector of employment was derived from the occupational status of the respondent in the 1995 census; therefore, this variable describes the spouses' employment sector only in the year 1995.

\subsubsection{Employment Stability}

In order to measure employment stability, the percentage of employed months out of all marriage months is computed. 


\subsection{Educational Measures}

\subsubsection{Highest Educational Degree of the Wife and of the Husband}

This variable is measured by five dummy variables, one for each degree: less than secondary, secondary education without a matriculation certificate, secondary education with a matriculation certificate (reference category), a post-secondary certificate, and an academic degree (BA, MA, or $\mathrm{PhD}$ ). For $1 \%$ of the women and $1 \%$ of the men, the educational level is defined as "other." This category is also included as a dummy.

\subsubsection{Educational Homogamy}

Three groups of couples are represented by dummy variables: the wife's education is lower than the husband's (reference category), the wife's and husband's educational levels are equal, and the wife's education is higher than the husband's. If at least one of the spouses has an "other" educational degree, the degree of educational homogamy is defined as "unknown."

\subsection{Other Control Variables}

Home ownership is regarded as marital investment, and is expected to have a negative effect on marriage dissolution (Ono 1998; South and Spitze 1986). This variable equals 1 if spouses own their home in 1995, and 0 otherwise. Another marital investment, which is expected to constitute a barrier to divorce, is having children, and especially young ones (Andersson 1997; Becker et al. 1977; Lillard and Waite 1993). The "number of children aged 0-5" variable is composed of four dummy variables: no children (reference category), 1 child, 2 children, and 3 or more children. As Ultra-Orthodox families in Israel form a special case of specialization, in which the husband usually does not work and the wife is the main breadwinner; and at the same time divorce risks among this religious group are low (Peres and Katz 1991), it is important to control for this effect in our model. Following Dahan (1998), religiosity is operationalized by using a dichotomous variable which indicates whether the husband studied in a Yeshiva (an academy for the advanced study of Jewish texts) or not, since mostly very religious Jews attend this institution. According to a document prepared by National Economic Council in the Prime Minister's Office in Israel (Levin and Ha-Cohen 2010), using the parameter of studies in a Yeshiva is the best available indicator to identify UltraOrthodox households in Israel. The variable "Highly religious" receives the value 1 if the husband studies in the Yeshiva, and 0 otherwise.

The ethnic origin variable, which is combined with generation in the country, is divided into seven categories, and includes separate proxy dummy for new immigrants from former USSR [full description of this variable can be found in Raz-Yurovich (2010)]. Previous research shows that new immigrants from the former USSR have higher divorce rates at the time of immigration, in comparison to the general population in Israel (Dovrin 2005). Therefore, this group is expected to 
have higher divorce risks in comparison to native-born Israelis and to other immigrants, even among those who married in Israel. In addition, it is expected that Oriental Jews will have lower divorce risks in comparison to Western Jews, in both first and second generations, due to their more traditional familial values (Kraus 2002; Peres and Katz 1991). Although ethnic homogamy was found in previous research to affect divorce in Israel (Lewin 2006), it is beyond the scope of this research.

The age difference between the spouses is also included in the analysis, because according to Becker et al. (1977) and Kalmijn et al. (2007), large age differences are believed to be destabilizing and may also be related to differences in income between the spouses. The age difference is measured by one dichotomous variable which is equal to 1 if the age difference is 9 years or more, and to 0 otherwise. Marriage duration as of 1995 is included as a control variable, and is measured by a separate set of dummy variables for each possible duration, between 0 and 5 years. Marriage duration of 5 years (for those who married in 1990) is the reference category. Age at marriage is included with both its linear and quadratic form for each spouse.

The descriptive statistics of the control variables appear in Table 4 in Appendix. Results for these variables can be found in Table 5 in Appendix.

\section{Method}

Six logistic regression models are performed in order to analyze the economic determinants of divorce, Models 1-6. First, in order to examine the overall effect of economic activity, which is also due to educational characteristics, we will include all the control variables in the analysis, apart from the educational variables. Later, in order to take into account the effect of education, we will also include the educational characteristics of the spouses in the analysis.

Each of the first three models includes a different salary measure of the couples, without controlling for their other employment characteristics. The first model includes the sum of the spouses' earnings, the second includes the average monthly earnings of each of the spouses, and the third includes the share of the wife's earnings with the sum of the spouses' earnings. Models 4-6 add to the salary variables in Models 1-3 the other employment characteristics of the spouses: sector of employment, number of hours invested in the labor force, and employment stability. Given that the salary might have a strong relationship with the other employment characteristics of the spouses, these models allow us to examine the effect of the salary with and without controlling for the other characteristics.

\section{Results}

Table 1 presents the means or percentages, and the standard deviations of the economic variables in this analysis. Means and standard deviations of the educational variables are presented in Appendix. 
Table 1 Means and standard deviations of the economic variables $(N=13,041)$

Note: For binary variables the mean represents the percentage of individuals receiving the value one

\begin{tabular}{llc}
\hline Variable & Mean (\%) & SD \\
\hline Log of the sum of couple's salary & 27.64 & 0.49 \\
Log of wife's salary & 15.01 & 0.73 \\
Log of husband's salary & 15.63 & 0.69 \\
Wife's share in household income & & \\
$\quad<25 \%$ & 0.23 & 0.42 \\
25-50\% & 0.60 & 0.49 \\
50-75\% & 0.15 & 0.36 \\
75-100\% & 0.02 & 0.13 \\
Sector of employment-wife & & \\
Private & 0.49 & 0.50 \\
Public & 0.33 & 0.47 \\
$\quad$ Unknown & 0.18 & 0.38 \\
Sector of employment-husband & & \\
Private & 0.66 & 0.47 \\
Public & 0.21 & 0.41 \\
$\quad$ Unknown & 0.13 & 0.33 \\
Labor market investment (per week) & & \\
$\quad$ Number of hours wife works & 34.75 & 12.89 \\
$\quad$ Number of hours husband works & 47.68 & 14.47 \\
Employment stability & & \\
Percentage of marriage months wife worked & 75.10 & 24.42 \\
Percentage of marriage months husband & 86.05 & 20.25 \\
$\quad$ worked & & \\
\hline
\end{tabular}

The odds ratios of the effects of the economic characteristics of the spouses on the risk of divorce, not controlling for the educational variables but including all the other control variables, are presented in Table 2. In line with the theories that assert a stabilizing effect of the wife's employment on marriage, Model 1 shows a negative effect of the spouses' joint earnings on divorce. Nonetheless, contrary to these theories, Model 2 shows that, because the effect of the spouses' contribution to the family's earnings is not symmetric among dual-earner couples, the effect of the husband's salary on divorce is negative and significant, while the effect of the wife's salary on divorce is negative but not significant. These results also suggest that, contrary to Becker's theory, an increase in the wife's earnings do not increase the risk of divorce.

Model 3 presents the results for the effect of the relative salary of the spouses (i.e., the effect of the wife's share in the household income), also controlling for the total earnings of the spouses. The results suggest that, in line with the status competition, gender display, bargaining model, and equal dependency theories, couples in which the wife contributes less than half of the family's income have lower odds of divorce than couples in which the wife earns as much as or more than her husband, and contributes 50 to $75 \%$ of the family's income. The effect for the 
Table 2 Odds ratios of the effect of economic characteristics on divorce, not controlling for the educational levels of the spouses

\begin{tabular}{|c|c|c|c|c|c|c|}
\hline Variable & $\begin{array}{l}\text { Model } 1 \\
\exp (b)\end{array}$ & $\begin{array}{l}\text { Model } 2 \\
\exp (b)\end{array}$ & $\begin{array}{l}\text { Model } 3 \\
\exp (b)\end{array}$ & $\begin{array}{l}\text { Model } 4 \\
\exp (b)\end{array}$ & $\begin{array}{l}\text { Model } 5 \\
\exp (b)\end{array}$ & $\begin{array}{l}\text { Model } 6 \\
\exp (b)\end{array}$ \\
\hline \multicolumn{7}{|l|}{ Salary } \\
\hline Log of the sum of couple's salary & $0.68^{* * *}$ & & $0.68 * * *$ & $0.72 *$ & & $0.72 * *$ \\
\hline Log of wife's salary & & 0.96 & & & 0.99 & \\
\hline Log of husband's salary & & $0.82 * * *$ & & & $0.85^{*}$ & \\
\hline \multicolumn{7}{|l|}{ Wife's share in household income } \\
\hline$<25 \%$ & & & $0.72 * *$ & & & $0.68^{*}$ \\
\hline $25-50 \%$ & & & $0.69 * * *$ & & & $0.68 * *$ \\
\hline $50-75 \%$ & & & 1 & & & 1 \\
\hline $75-100 \%$ & & & 0.42 & & & $0.39 *$ \\
\hline \multicolumn{7}{|l|}{ Sector of employment-wife } \\
\hline Private & & & & 1 & 1 & 1 \\
\hline Public & & & & $0.77 *$ & $0.77 *$ & $0.76^{*}$ \\
\hline \multicolumn{7}{|l|}{ Sector of employment-husband } \\
\hline Private & & & & 1 & 1 & 1 \\
\hline Public & & & & 1.12 & 1.12 & 1.13 \\
\hline \multicolumn{7}{|l|}{ Labor market investment (per week) } \\
\hline Number of hours wife works & & & & $1.02^{* * *}$ & $1.02 * * *$ & $1.02 * * *$ \\
\hline Number of hours husband works & & & & 1.01 & 1.01 & 1.01 \\
\hline \multicolumn{7}{|l|}{ Employment stability } \\
\hline $\begin{array}{l}\text { Percentage of marriage } \\
\text { months wife worked }\end{array}$ & & & & $0.99 * * *$ & $0.99 * * *$ & $0.99 * * *$ \\
\hline $\begin{array}{l}\text { Percentage of marriage } \\
\text { months husband worked }\end{array}$ & & & & $0.99 * *$ & $0.99 * *$ & $0.99 * *$ \\
\hline Constant & $16.7^{* * * *}$ & $10.2 * * *$ & $11.1 * * *$ & $13.25 * * *$ & 7.4 & 13.6 \\
\hline -2Loglikelihood & 3457.7 & 3461.5 & 3406.0 & 3406.1 & 3408.7 & 3395.8 \\
\hline df & 28 & 29 & 41 & 38 & 39 & 41 \\
\hline Number of couples & 13,041 & 13,041 & 13,041 & 13,041 & 13,041 & 13,041 \\
\hline Number of divorces & 403 & 403 & 403 & 403 & 403 & 403 \\
\hline
\end{tabular}

Note: All the control variables are included in this model, including dummies for cases that do not have information on working hours and sector in the 1995 census (not presented)

$* p<.05, * * p<.01, * * * p<.001$

highest share group (75-100\%) is negative but not significant compared to the share group of $50-75 \%$.

Models 4-6 add to Models 1-3 other employment characteristics of the spouses: sector of employment, labor market investment, and employment stability. The effects of the different salary measures do not change in these models following the inclusion of the other economic characteristics, apart from the effect of the highest share category in the wife's share of household income, which becomes more negative and significant. Nonetheless, as will be presented in Table 3, once educational level of the spouses is controlled for, this significant negative effect of 
Table 3 Odds ratios of the effect of economic characteristics on divorce, controlling for educational level of the spouses

\begin{tabular}{|c|c|c|c|c|c|c|}
\hline Variable & $\begin{array}{l}\text { Model } 1 \\
\exp (b)\end{array}$ & $\begin{array}{l}\text { Model } 2 \\
\exp (b)\end{array}$ & $\begin{array}{l}\text { Model } 3 \\
\exp (b)\end{array}$ & $\begin{array}{l}\text { Model } 4 \\
\exp (b)\end{array}$ & $\begin{array}{l}\text { Model } 5 \\
\exp (b)\end{array}$ & $\begin{array}{l}\text { Model } 6 \\
\exp (b)\end{array}$ \\
\hline \multicolumn{7}{|l|}{ Salary } \\
\hline Log of the sum of couple's salary & $0.75^{* *}$ & & $0.76^{*}$ & 0.82 & & 0.83 \\
\hline Log of wife's salary & & 1.01 & & & 1.06 & \\
\hline Log of husband's salary & & $0.85 * *$ & & & 0.88 & \\
\hline \multicolumn{7}{|l|}{ Wife's share in household income } \\
\hline$<25 \%$ & & & $0.69^{*}$ & & & $0.65^{*}$ \\
\hline $25-50 \%$ & & & $0.66^{* *}$ & & & $0.65^{* *}$ \\
\hline $50-75 \%$ & & & 1 & & & 1 \\
\hline $75-100 \%$ & & & 0.47 & & & 0.44 \\
\hline \multicolumn{7}{|l|}{ Wife's educational level } \\
\hline Less than secondary & $1.94 *$ & $1.98^{*}$ & $1.97 *$ & $1.88^{*}$ & $1.92 *$ & $1.91 *$ \\
\hline $\begin{array}{l}\text { Secondary without matriculation } \\
\text { certificate }\end{array}$ & $1.37 *$ & $1.40^{*}$ & $1.40^{*}$ & 1.34 & 1.35 & 1.36 \\
\hline $\begin{array}{l}\text { Secondary with matriculation } \\
\text { certificate }\end{array}$ & 1 & 1 & 1 & 1 & 1 & 1 \\
\hline Post-secondary certificate & $0.62^{*}$ & $0.62^{*}$ & $0.61^{* *}$ & $0.65^{*}$ & $0.64 *$ & $0.63^{*}$ \\
\hline Academic degree & $0.57^{*}$ & $0.56^{* *}$ & $0.56^{* *}$ & $0.58^{*}$ & $0.57^{*}$ & $0.57^{*}$ \\
\hline \multicolumn{7}{|l|}{ Husband's educational level } \\
\hline Less than secondary & 0.95 & 0.97 & 0.93 & 0.91 & 0.92 & 0.90 \\
\hline $\begin{array}{l}\text { Secondary without matriculation } \\
\text { certificate }\end{array}$ & 0.96 & 0.96 & 0.97 & 0.95 & 0.95 & 0.95 \\
\hline $\begin{array}{l}\text { Secondary with matriculation } \\
\text { certificate }\end{array}$ & 1 & 1 & 1 & 1 & 1 & 1 \\
\hline Post-secondary certificate & 0.85 & 0.85 & 0.87 & 0.85 & 0.84 & 0.86 \\
\hline Academic degree & 1.00 & 1.00 & 1.00 & 0.99 & 0.98 & 1.00 \\
\hline \multicolumn{7}{|l|}{ Educational homogamy } \\
\hline $\begin{array}{l}\text { Wife's education lower than } \\
\text { husband's }\end{array}$ & 1 & 1 & 1 & 1 & 1 & 1 \\
\hline $\begin{array}{l}\text { Wife's education equal to } \\
\text { husband's }\end{array}$ & 1.19 & 1.19 & 1.20 & 1.18 & 1.17 & 1.19 \\
\hline $\begin{array}{l}\text { Wife's education higher than } \\
\text { husband's }\end{array}$ & 1.67 & 1.66 & 1.67 & 1.68 & 1.67 & 1.68 \\
\hline \multicolumn{7}{|l|}{ Sector of employment—wife } \\
\hline Private & & & & 1 & 1 & 1 \\
\hline Public & & & & 0.85 & 0.85 & 0.84 \\
\hline \multicolumn{7}{|l|}{ Sector of employment—husband } \\
\hline Private & & & & 1 & 1 & 1 \\
\hline Public & & & & 1.15 & 1.15 & 1.15 \\
\hline \multicolumn{7}{|l|}{ Labor market investment (per week) } \\
\hline Number of hours wife works & & & & $1.02 * * *$ & $1.02 * *$ & $1.02 * * *$ \\
\hline Number of hours husband works & & & & 1.01 & 1.01 & 1.01 \\
\hline
\end{tabular}


Table 3 continued

\begin{tabular}{|c|c|c|c|c|c|c|}
\hline Variable & $\begin{array}{l}\text { Model } 1 \\
\exp (b)\end{array}$ & $\begin{array}{l}\text { Model } 2 \\
\exp (b)\end{array}$ & $\begin{array}{l}\text { Model } 3 \\
\exp (b)\end{array}$ & $\begin{array}{l}\text { Model } 4 \\
\exp (b)\end{array}$ & $\begin{array}{l}\text { Model } 5 \\
\exp (b)\end{array}$ & $\begin{array}{l}\text { Model } 6 \\
\exp (b)\end{array}$ \\
\hline \multicolumn{7}{|l|}{ Employment stability } \\
\hline $\begin{array}{l}\text { Percentage of marriage } \\
\text { months wife worked }\end{array}$ & & & & $0.99 * * *$ & $0.99 * * *$ & $0.99 * * *$ \\
\hline $\begin{array}{l}\text { Percentage of marriage } \\
\text { months husband worked }\end{array}$ & & & & $0.99 * *$ & $0.99 * *$ & $0.99 *$ \\
\hline Constant & $10.9 * * *$ & $5.92 * *$ & $11.07 * * *$ & $7.59 *$ & 3.41 & $7.56^{*}$ \\
\hline-2 Loglikelihood & 3416.6 & 3417.1 & 3406.0 & 3372.1 & 3371.8 & 3361.0 \\
\hline df & 38 & 39 & 41 & 48 & 49 & 51 \\
\hline Number of couples & 13,041 & 13,041 & 13,041 & 13,041 & 13,041 & 13,041 \\
\hline Number of divorces & 403 & 403 & 403 & 403 & 403 & 403 \\
\hline
\end{tabular}

Note: All the control variables and the educational level variables are included in this model, including dummies for cases that do not have information on working hours and sector in the 1995 census (not presented)

$* p<.05, * * p<.01, * * * p<.001$

the highest share group becomes insignificant. In all three of the models, the employment of the wife in the public sector significantly reduces divorce risks. The husband's sector of employment is not found to affect divorce risks. Regarding labor market investment, the findings indicate that each additional hour the wife invests in the labor market increases the odds of divorce by $2 \%$. The effect of the husband's labor market investment does not significantly affect divorce risk. The positive effect on divorce found for the wife's labor market investment, controlling for her salary, can also be interpreted as the effect of the amount of time she is absent from home on divorce (Greenstein 1990).

Regarding the employment stability of the spouses, Models 4-6 suggest that the employment stability of both the wife and the husband significantly decreases divorce risk. ${ }^{4}$

Table 3 presents the same models as Table 2, this time controlling for the educational levels of the spouses. The results for the educational measures are also presented. After controlling for education, the effects of the different salary measures in Models 1-3 resemble those in Table 2. The results for education across all models suggest that the higher the level of education of the wife, the lower the couple's divorce risk, controlling for economic characteristics. The negative effect of the wife's educational level on divorce, controlling for her economic characteristics, are in line with Becker's et al. (1977) assertion that highly educated individuals will have higher gains from marriage, and therefore lower gains from divorce (ibid., p. 1146).

This is because highly educated spouses might hold high levels of market and non market skills, such as communication, social, and cognitive skills which might

\footnotetext{
${ }^{4}$ A tolerance test, to check for possible multi-collinearity between all the economic explanatory variables, showed that there is no apparent problem with multi-collinearity.
} 
contribute to the marriage stability. The effect of the husband's educational level is found to be insignificant across all models, and so is the effect of the educational homogamy of the spouses. Nonetheless, a separate analyses (not presented) which include the educational level of each spouse separately together with the educational homogamy, show negative effect of men's educational level on divorce. Moreover, in the analysis which include the wife's educational level and educational homogamy, the results show negative effect of women's education, and a higher risk of divorce among couples in which the wife's educational level is higher than her husband's.

In Models 4-6, when we control both for education and for the other employment characteristics of the spouses, the significant negative effect of the sum of couple's salary on divorce becomes insignificant, as does the negative effect of the husband's salary in Model 5. Moreover, in Models 4-6, the effect of public sector employment of the wife becomes insignificant. This means that, in Models 4-6, the salary measures have no statistically significant effects with the exception of the divorcepromoting effect of low percentage contribution of the wife, which might suggest that money as such does not matter much.

\section{Discussion}

The increase in dual-earner families in most Western developed countries, and the parallel decline in single-earner families, in which the husband is the sole breadwinner, raise questions concerning the economic determinants of divorce among families in which the wife participates in the labor force to different degrees. The analysis of dual-earner couples challenges some of the traditional theoretical perspectives, which were molded in the male breadwinner form. In this paper, we investigate the validity of two main groups of theories: one which asserts that women's work has a destabilizing effect on marriage, and assumes asymmetry between the spouses; and another which claims that women's employment has a stabilizing effect, and assumes that relations between the spouses are symmetric. Most of these theoretical perspectives tend to operationalize economic standing by the earnings of the spouses, and neglect to consider the possible effect of other economic characteristics, such as the number of hours invested in the labor force or employment stability, which might be relevant to the work-family conflict and affect the spouses' propensity to divorce. The inclusion of other employment characteristics of the spouses in this study does not affect the explanatory power of the different salary measures, but it contributes to the understanding of the complicated work-family conflict among dual-earner couples.

Overall, the results of our examination of dual-earner couples in Israel do not appear to support theories that assert the presence of symmetry between the spouses. Our results fail to confirm the women's economic independence hypothesis of Becker, as higher earnings for the wife are not found to increase marriage dissolution risk. In addition, in line with the theories emphasizing income pooling or economic partnership, we found that, among dual-earner couples, the higher the shared salaries of the spouses, the lower the risk of divorce. Nonetheless, the results 
demonstrate that the basic assumption of symmetry between the spouses in the theories of income pooling does not hold, and that the wife's earnings do not equal her husband's earnings. This is apparent in the non-significant effect of the salary of the wife, in comparison to the negative and significant effect of the husband's salary on divorce. Moreover, the results for the effect of the wife's share in the family's earnings also demonstrate that there is an asymmetry in the household, because couples in which the wife earns as much as or more than her husband were found to have higher divorce risks than couples in which the husband is the main breadwinner and the wife is a secondary breadwinner. These findings regarding the relative salary are in line with the status competition and gender display theories, which claim that couples in which the wife has higher economic status than her husband will be more vulnerable to divorce, due to the competition that these status differences evoke.

Our results for the effect of the wife's relative share in earnings also tend to support the equal dependency theory, and could suggest that dual-earner spouses who contribute nearly the same percentage of the household income might have the lowest degree of commitment to each other, and therefore experience the highest divorce risks. These findings regarding relative salaries are also in line with the bargaining models, which claim that the fraction of resources controlled by the wife reflect the bargaining power she has, and might increase the divorce threat-point; i.e., the utility she will receive in the event of divorce (Pollak 1994).

The degree of asymmetry between the partners is also apparent in the significantly positive effect that wives' labor force investments have on divorce, compared to the non-significant effect of the husbands' investments; and also in the significant negative effect of public sector employment of the wife, but not of the husband (in the models which do not control for education).

Regarding the effect of the husband's economic characteristics on divorce, our results tend to support the basic, underlying assumption found in all of the theories discussed: i.e., that the husband's earnings have a stabilizing effect on marriage. The negative and significant effect of the husband's employment stability on divorce further suggests that employment instability or unemployment of the husband increases divorce risks, as was found in previous literature (Charles and Stephens 2004; Jalovaara 2003). These findings might point to the unchanging role of husbands as the main breadwinners, even among dual-earner families.

It appears that there is a dualism among dual-earner couples. On the one hand, the stable employment of both partners and high shared earnings increase marriage stability, and therefore reduce divorce risk. On the other hand, if the wife earns the same as or more than her husband, the risk of divorce increases. A similar effect is found if the wife invests many hours in the labor market, and is therefore absent from home more often. This dualism is most probably affected by the need to combine work and family life among dual-earner couples, in an era in which dual incomes are both a necessity and means of increasing the family's standards of living. That is why demanding jobs, such as those in the private sector, which require the investment of many working hours and absenteeism from the second shift, increase the work-family conflict, and thus the marital instability. In a country such as Israel, where the family is very central in individuals' lives, and where 
women are expected to take on the main responsibilities for the household chores and for raising the children, regardless of their level of labor market activity (Glickman et al. 2003; Izraeli 1997), this dualism might be stronger than in other countries.

Our ability to control for both economic activity and educational level, allowed us to measure the pure effect of the spouses' educational level on the risk of divorce, and to solve the puzzle regarding the effect of women's education, as is presented in Becker et al. (1977). Our findings demonstrate a negative educational gradient in marital disruption among dual-earner couples in Israel, controlling for economic activity. The inclusion of both employment variables and educational characteristics in our models further revealed the mechanisms which operate in the relationships between economic activity and marital stability, and demonstrate that money as such does not matter. As only the effect of the wife's share in earnings remains significant following the inclusion of employment and educational characteristics, it seems that asymmetry between the spouses is the most important determinant of marital stability.

The findings of this study are in line with studies which have found that gender inequality is apparent not only at the societal level or in the labor market, but also within households (Aharon 2006; Stier and Lewin-Epstein 2000; Stier and Mandel 2009). This study on divorce among dual-earner couples demonstrates that, after relaxing the assumption of full specialization, certain degrees of specialization still remain among couples, which might affect the economic characteristics of the spouses and maintain women's dual role as both the secondary breadwinner and the primary homemaker.

Acknowledgments I am incredibly grateful to Prof. Barbara S. Okun (The Hebrew University of Jerusalem) for her invaluable comments and for supervising this work when I was a PhD student at The Hebrew University of Jerusalem, Israel. Moreover, I would like to thank Prof. Jona Schellekens (The Hebrew University of Jerusalem), Prof. Joshua R. Goldstein (Max Planck Institute for Demographic Research), Prof. Haya Stier (Tel Aviv University), Prof. Patricia A. McManus (Indiana University), and anonymous reviewers of this article for their helpful comments on earlier versions of this article. I would also like to thank Dr. Dafna Hacker (Tel-Aviv University) and Dr. Amit Kaplan (Academic College TelAviv -Yafo) for their help. I also acknowledge the Israel Social Sciences Data Center (ISDC) at the Hebrew University of Jerusalem as my data distributer, and Statistics Israel as the data coordinator. I am also grateful for the Minerva and ISEF foundations. Certain aspects of this article were presented at the Workshop on Register-Based Demographic Research, organized by the Demography Department at Stockholm University, September 27, 2010. In addition, this work was presented at the 2011 spring meeting of the Research Committee on Social Stratification and Mobility (RC28) of the International Sociological Association (ISA), University of Essex, Colchester, UK, April 15, 2011. This paper was also presented in a roundtable of the sociology of the family section at the American Sociological Association 106th Annual Meeting, Las Vegas, Nevada, USA, August 21, 2011. Moreover, this work was presented at the Conference on the Economics of the Family in Honor of Gary S. Becker, Paris, France, October 6, 2011.

\section{Appendix}

See Tables 4 and 5. 
Table 4 Means and standard deviations of the control variables $(N=13,041)$

\begin{tabular}{|c|c|c|}
\hline Variable & Mean $(\%)$ & $\mathrm{SD}$ \\
\hline \multicolumn{3}{|l|}{ Duration dependence } \\
\hline Duration 0 years & 0.12 & 0.32 \\
\hline Duration 1 years & 0.16 & 0.36 \\
\hline Duration 2 years & 0.18 & 0.38 \\
\hline Duration 3 years & 0.19 & 0.39 \\
\hline Duration 4 years & 0.18 & 0.39 \\
\hline Duration 5 years & 0.18 & 0.38 \\
\hline Home ownership (vs. no) & 0.61 & 0.49 \\
\hline \multicolumn{3}{|l|}{ Number of children aged $0-5$} \\
\hline 0 & 0.36 & 0.48 \\
\hline 1 & 0.43 & 0.50 \\
\hline 2 & 0.19 & 0.39 \\
\hline 3 or more & 0.02 & 0.15 \\
\hline Very religious (vs. not) & 0.03 & 0.17 \\
\hline Age difference is nine or more years & 0.05 & 0.22 \\
\hline Husband's age at marriage & 27.29 & 3.88 \\
\hline Wife's age at marriage & 24.57 & 3.50 \\
\hline \multicolumn{3}{|l|}{ Wife's education } \\
\hline Less than secondary & 0.04 & 0.20 \\
\hline Secondary without matriculation certificate & 0.25 & 0.43 \\
\hline Secondary with matriculation certificate & 0.27 & 0.44 \\
\hline Post-secondary certificate & 0.16 & 0.36 \\
\hline Academic degree & 0.28 & 0.45 \\
\hline Other & 0.01 & 0.10 \\
\hline \multicolumn{3}{|l|}{ Educational homogamy } \\
\hline Wife's education lower than husband's & 0.20 & 0.40 \\
\hline Wife's education equal to husband's & 0.43 & 0.49 \\
\hline Wife's education higher than husband's & 0.35 & 0.48 \\
\hline Unknown & 0.02 & 0.13 \\
\hline \multicolumn{3}{|l|}{ Ethnic origin and generation in the country-wife } \\
\hline Former Soviet Union immigrants who immigrated starting 1990 & 0.05 & 0.22 \\
\hline First-generation Western Jews & 0.08 & 0.26 \\
\hline Second-generation Western Jews & 0.11 & 0.31 \\
\hline First-generation Oriental Jews & 0.03 & 0.18 \\
\hline Second-generation Oriental Jews & 0.38 & 0.49 \\
\hline Mixed ethnicity & 0.05 & 0.21 \\
\hline Third-generation Israelis & 0.31 & 0.46 \\
\hline \multicolumn{3}{|l|}{ Ethnic origin and generation in the country-husband } \\
\hline Former Soviet Union immigrants who immigrated starting 1990 & 0.04 & 0.19 \\
\hline First-generation Western Jews & 0.08 & 0.28 \\
\hline Second-generation Western Jews & 0.13 & 0.33 \\
\hline
\end{tabular}


Table 4 continued

\begin{tabular}{lcc}
\hline Variable & Mean $(\%)$ & SD \\
\hline First-generation Oriental Jews & 0.06 & 0.23 \\
Second-generation Oriental Jews & 0.40 & 0.49 \\
Mixed ethnicity & 0.04 & 0.19 \\
Third-generation Israelis & 0.26 & 0.44 \\
\hline
\end{tabular}

Table 5 Baseline logistic regression model of divorce within 3 years

\begin{tabular}{|c|c|c|c|}
\hline Variable & $b$ & $p$ & $\exp (b)$ \\
\hline \multicolumn{4}{|l|}{ Duration dependence } \\
\hline Duration 0 years & -0.42 & 0.07 & 0.66 \\
\hline Duration 1 years & -0.21 & 0.30 & 0.81 \\
\hline Duration 2 years & -0.29 & 0.14 & 0.75 \\
\hline Duration 3 years & -0.07 & 0.71 & 0.94 \\
\hline Duration 4 years & -0.23 & 0.22 & 0.80 \\
\hline Duration 5 years & 1 & - & - \\
\hline Home ownership (vs. no) & -0.42 & 0.00 & 0.66 \\
\hline \multicolumn{4}{|l|}{ Number of children aged $0-5$} \\
\hline 0 & 1 & - & - \\
\hline 1 & -0.39 & 0.00 & 0.68 \\
\hline 2 & -0.95 & 0.00 & 0.39 \\
\hline 3 or more & -0.97 & 0.04 & 0.38 \\
\hline Very religious (vs. not) & -0.66 & 0.09 & 0.52 \\
\hline Age difference is 9 or more years & 0.48 & 0.06 & 1.62 \\
\hline Husband's age at marriage & -0.30 & 0.01 & 0.74 \\
\hline (Husband's age at marriage) $^{2}$ & 0.01 & 0.02 & 1.01 \\
\hline Wife's age at marriage & -0.34 & 0.01 & 0.71 \\
\hline$(\text { Wife's age at marriage })^{2}$ & 0.01 & 0.03 & 1.01 \\
\hline \multicolumn{4}{|l|}{ Wife's ethnic origin } \\
\hline Former Soviet Union immigrants who immigrated starting 1990 & 1 & - & - \\
\hline First-generation Western Jews & -0.67 & 0.03 & 0.51 \\
\hline Second-generation Western Jews & -1.21 & 0.00 & 0.30 \\
\hline First generation Eastern Jews & -0.81 & 0.05 & 0.45 \\
\hline Second-generation Eastern Jews & -0.83 & 0.00 & 0.44 \\
\hline Mixed ethnicity & -0.94 & 0.01 & 0.39 \\
\hline Third-generation Israelis & -0.95 & 0.00 & 0.39 \\
\hline \multicolumn{4}{|l|}{ Husband's ethnic origin } \\
\hline Former Soviet Union immigrants who immigrated starting 1990 & 1 & - & - \\
\hline First-generation Western Jews & -0.06 & 0.86 & 0.94 \\
\hline Second-generation Western Jews & 0.44 & 0.19 & 1.56 \\
\hline First-generation Eastern Jews & 0.01 & 1.00 & 1.01 \\
\hline
\end{tabular}


Table 5 continued

\begin{tabular}{llll}
\hline Variable & $b$ & $p$ & $\exp (b)$ \\
\hline Second-generation Eastern Jews & 0.35 & 0.28 & 1.42 \\
Mixed ethnicity & 0.75 & 0.05 & 2.12 \\
Third generation Israelis & 0.39 & 0.23 & 1.48 \\
Constant & 7.25 & 0.00 & 1402.6 \\
-2Loglikelihood & & 3472.0 & \\
df & & 27 \\
Number of couples & & \multicolumn{2}{c}{13,041} \\
Number of divorces & & \multicolumn{2}{c}{403} \\
\hline
\end{tabular}

Note: The effects of the control variables do not change following the inclusion of the economic variables. "Other" categories of educational level are controlled for but not presented, as is an "unknown" category of educational homogamy

\section{References}

Aharon, G. (2006). Inequality in the family: Married women's economic dependency in Israel across time. Israeli Sociology, 8(1), 87-112 (Hebrew).

Andersson, G. (1997). The impact of children on divorce risks of Swedish women. European Journal of Population, 13, 109-145.

Becker, G. S. (1991). A treatise on the family. Cambridge: Harvard University Press.

Becker, G. S., Landes, E. M., \& Michael, R. T. (1977). An economic analysis of marriage instability. Journal of Political Economy, 85(6), 1141-1187.

Blossfeld, H.-P., \& Drobnic, S. (Eds.). (2001). Careers of couples in contemporary societies: From male breadwinner to dual earner families. Oxford: Oxford University Press.

Blossfeld, H.-P., \& Müller, R. (2002). Union disruption in comparative perspective: The role of assortative partner choice and careers of couples. International Journal of Sociology, 32(4), 3-35.

Blush-Kleinman, V., \& Sherlin, S. (1999). Cohabitation among young adults in Israel. Society and Welfare (Hevra ve revaha), 4, 461-484 (Hebrew).

Brines, J. (1994). Economic dependency, gender, and the division of labor at home. American Journal of Sociology, 100(3), 652-688.

Castles, F. G. (2003). The world turned upside down: Below replacement fertility, changing preferences and family-friendly public policy in 21 OECD countries. Journal of European Social Policy, 13, 209-228.

Charles, K. K., \& Stephens, M. (2004). Job displacement, disability, and divorce. Journal of Labor Economics, 22(2), 489-522.

Cherlin, A. J. (2000). Toward a new home socioeconomics of union formation. In L. J. Waite, C. Bachrach, M. Hindin, E. Thomson, \& A. Thornton (Eds.), The ties that bind-Perspectives on marriage and cohabitation (pp. 283-301). Hawthorne, NY: Aldine De Gruyter.

Cooke, L. P. (2006). "Doing" gender in context: Household bargaining and risk of divorce in Germany and the United States. American Journal of Sociology, 112(2), 442-472.

Dahan, M. (1998). The Ultra-Orthodox Jews and municipal authority, Part I. Research Series No. 79. Jerusalem: The Jerusalem Institute for Israel Studies (Hebrew).

De Graaf, P. M., \& Kalmijn, M. (2006). Divorce motives in a period of rising divorce-Evidence from a Dutch life-history survey. Journal of Family Issues, 27(4), 483-505.

Dovrin, N. (2005). Divorce in Israel: The extent of divorce and the factors affecting the probability of divorce. Jerusalem: Central Bureau of Statistics (Hebrew).

Dribe, M., \& Stanfors, M. (2010). Family life in power couples: Continued childbearing and union stability among the educational elite in Sweden, 1991-2005. Demographic Research, 23-30, 847-878. 
European Commission, Eurostat. (2010). Europe in Figures-Eurostat Yearbook 2010. Luxembourg: Office for Official Publications of the European Communities.

Fogel, N. (2005). Cohabitation in Israel. Israel: The Central Bureau of Statistics (Hebrew).

Glickman, A., Oren A., \& Lewin-Epstein, N. (2003). New Israeli family? Gender roles and division of household labor at the beginning of the 21 st century. Deot Ba'am no. 8. The B.I. and Lucille Cohen Institute for Public Opinion Research (Hebrew).

Goffman, E. (2007). Gender display. In L. Tiger \& H. T. Fowler (Eds.), Female hierarchies (pp. 60-86). New Brunswick: Transaction Publishers.

Greenstein, T. N. (1990). Marital disruption and the employment of married women. Journal of Marriage and Family, 52, 657-676.

Hansen, H.-T. (2005). Unemployment and marital dissolution-A panel data study of Norway. European Sociological Review, 21(2), 135-148.

Härkönen, J., \& Dronkers, J. (2006). Stability and change in the educational gradient of divorce: A comparison of seventeen countries. European Sociological Review, 22(5), 501-517.

Heckert, A. D., Nowak, T. C., \& Snyder, K. A. (1998). The impact of husbands' and wives' relative earnings on marital disruption. Journal of Marriage and the Family, 60, 690-703.

Henz, U., \& Jonsson, J. O. (2003). Union disruption in Sweden-Does economic dependency inhibit separation? International Journal of Sociology, 33(1), 3-39.

Higgins, C. A., \& Duxbury, L. E. (1992). Work-family conflict: A comparison of dual-career and traditional-career men. Journal of Organizational Behavior, 13(4), 389-411.

Higgins, C. A., Duxbury, L. E., \& Irving, R. H. (1992). Work-family conflict in the dual-career family. Organizational Behavior and Human Decision Processes, 51(1), 51-75.

Israel Central Bureau of Statistics. (2010a). Households and families: Demographic characteristics 20072008 according to labor force surveys. Jerusalem: State of Israel (Hebrew). Accessed December 20, 2011 from http://www.cbs.gov.il/publications10/households_families07_08/pdf/h_print.pdf.

Israel Central Bureau of Statistics. (2010b). Press release: Social survey 2009—Religiosity in IsraelCharacteristics of different groups. Jerusalem: State of Israel (Hebrew). Accessed December 20, 2011 from http://www.cbs.gov.il/hodaot2010n/19_10_101b.pdf.

Israel Central Bureau of Statistics. (Several years). Statistical Abstract 1996, 1998, 2009, 2011. Jerusalem: State of Israel.

ISSP. (2002). Family and changing gender roles III.

Izraeli, D. (1997). Culture, policy and women in dual-earner families in Israel. In R. Veler \& R. Cohen (Eds.), Family and wisdom: Current look on the family (pp. 80-107). Jerusalem: The Ministry of Education (Hebrew).

Jalovaara, M. (2001). Socio-economic status and divorce in first marriages in Finland 1991-93. Population Studies, 55, 119-133.

Jalovaara, M. (2003). The joint effects of marriage partners' socioeconomic positions on the risk of divorce. Demography, 40(1), 67-81.

Jensen, P., \& Smith, N. (1990). Unemployment and marital dissolution. Journal of Population Economics, 3, 215-229.

Kalmijn, M. (2011). The influence of men's income and employment on marriage and cohabitation: Testing Oppenheimer's theory in Europe. European Journal of Population, 27(3), 269-293.

Kalmijn, M., Loeve, A., \& Manting, D. (2007). Income dynamics in couples and the dissolution of marriage and cohabitation. Demography, 44(1), 159-179.

Kraus, V. (2002). Secondary breadwinners: Israeli women in the labor force. Westport, CT: Praeger.

Levin, H., \& Ha-Cohen, R. (2010). Techniques to quantity identification and characterization of the Haredi sector (Hebrew). The Prime Minister Office: State of Israel. Accessed December 25, 2011 from http://www.pmo.gov.il/NR/rdonlyres/7D1E8870-4073-43D2-8B78-0BA865572320/0/shitotcharedim 110710.pdf.

Lewin, T. A. (2006). Divorce in Israel: Demographic and social aspects. Israeli Sociology, 8(1), 65-85 (Hebrew).

Lillard, L. A., \& Waite, L. J. (1993). A joint model of marital childbearing and marital disruption. Demography, 30(4), 653-681.

Lundberg, S., \& Pollak, R. A. (1996). Bargaining and distribution in marriage. Journal of Economic Perspectives, 10(4), 139-158.

Lyngstad, T. H. (2011). Does community context have an important impact on divorce risk? A fixedeffects study of twenty Norwegian first-marriage cohorts. European Journal of Population, 27(1), $57-77$. 
Mandel, H., \& Semyonov, M. (2006). A welfare state paradox: State interventions and women's employment opportunities in 22 Countries. American Journal of Sociology, 111(6), 1910-1949.

Manser, M., \& Brown, M. (1980). Marriage and household decision-making: A bargaining analysis. International Economic Review, 21(1), 31-44.

Matysiak, A., Styrc, M., \& Vignoli, D. (2011). The educational gradient in marital disruption: A metaanalysis of European longitudinal research. Università degli Studi di Firenze Working Paper $2011 / 13$.

Moen, P., \& Sweet, S. (2003). Time clocks: Couples' work hour strategies. In P. Moen (Ed.), It's about time: Career strains, strategies, and successes (pp. 17-34). Ithaca, NY: Cornell University Press.

Moffitt, R. A. (2000). Female wages, male wages, and the economic model of marriage: The basic evidence. In L. J. Waite, C. Bachrach, M. Hindin, E. Thomson, \& A. Thornton (Eds.), The ties that bind-Perspectives on marriage and cohabitation (pp. 302-319). Hawthorne, NY: Aldine De Gruyter.

Nilsson, W. (2008). Unemployment, splitting up, and spousal income replacement. Labour, 22(1), 73106.

Nock, S. L. (1995). Commitment and dependency in marriage. Journal of Marriage and Family, 57, 503514.

Nock, S. L. (2001). The marriage of equally dependent spouses. Journal of Family Issues, 22(6), 756777.

Okun, B. S. (2012). Seculars in a religious society: Fertility of Jews in Israel. A Paper was presented at the Israeli Sociological Society annual meeting, February 2012.

Okun, B. S., Oliver, A. L., \& Khait-Marelly, O. (2007). The public sector, family structure, and labor market behavior: Jewish mothers in Israel. Work and Occupations, 34(2), 174-204.

Ono, H. (1998). Husbands' and wives' resources and marital dissolution. Journal of Marriage and the Family, 60, 674-689.

Oppenheimer, V. K. (1977). The sociology of women's economic role in the family. American Sociological Review, 42, 387-406.

Oppenheimer, V. K. (1997). Women's employment and the gain to marriage: The specialization and trading model. Annual Review of Sociology, 23, 431-453.

Parsons, T. (1940). An analytical approach to the theory of social stratification. American Journal of Sociology, 45(6), 841-862.

Peres, Y., \& Katz, R. (1991). The family in Israel: Transition and continuity. In L. Shamgar-Handlman \& R. Bar-Yosef (Eds.), Families in Israel (pp. 9-32). Jerusalem: Academon (Hebrew).

Pollak, R. A. (1994). For better or worse: The roles of power in models of distribution within marriage. AEA Papers and Proceedings, 84(2), 148-152.

Poortman, A.-R., \& Kalmijn, M. (2002). Women's labour market position and divorce in the Netherlands: Evaluating economic interpretations of the work effect. European Journal of Population, 18, 175-202.

Raz-Yurovich, L. (2010). Men's and women's economic activity and first marriage: Jews in Israel, 1987-1995. Demographic Research, 22-29, 933-964.

Rogers, S. J. (2004). Dollars, dependency, and divorce: Four perspectives on the role of wives' income. Journal of Marriage and Family, 66, 59-74.

Schoen, R., Astone, N. M., Rothert, K., Standish, N. J., \& Kim, Y. J. (2002). Women's employment, marital happiness, and divorce. Social Forces, 81(2), 643-662.

South, S. J., \& Spitze, G. (1986). Determinants of divorce over the marital life course. American Sociological Review, 51, 583-590.

Spitze, G., \& South, S. J. (1985). Women's employment, time expenditure, and divorce. Journal of Family Issues, 6, 307-329.

Stevenson, B., \& Wolfers, J. (2007). Marriage and divorce: Changes and their driving forces. Journal of Economic Perspectives, 21(2), 27-52.

Stier, H. (2010). The end of the single-earner era: Dual-earner families in Israel. In L. Kulik \& V. Milbauer (Eds.), Working families in Israel. Tel-Aviv: Hamichlala Le-Minhal (Hebrew).

Stier, H., \& Lewin-Epstein, N. (2000). Women's part-time employment and gender inequality in the family. Journal of Family Issues, 21(3), 390-410.

Stier, H., \& Mandel, H. (2009). Inequality in the family: The institutional aspects of women's earning contribution. Social Science Research, 38, 594-608.

Toren, N. (2003). Tradition and transition: Family change in Israel. Gender Issues, 21(2), 60-76. 
United States Department of Health and Human Services. (2010). National Vital Statistics Reports, Vol. 58, No. 25. Accessed December 20, 2011 from http://www.cdc.gov/nchs/data/nvsr/nvsr58/nvsr58_ 25.pdf.

Waite, L. J., \& Nielsen, M. (2001). The rise of the dual-earner family, 1963-1997. In R. Hertz \& N. L. Marshall (Eds.), Working families: The transformation of the American home (pp. 23-41). Berkeley: University of California Press.

West, C., \& Zimmerman, D. H. (1987). Doing gender. Gender and Society, 1(2), 125-151. 